\title{
VPLYV RELIÉFU NA ROZLOŽENIE ATMOSFÉRICKÝCH ZRÁŽOK NA SLOVENSKU PRI JUŽNÝCH CYKLONÁLNYCH SITUÁCIÁCH
}

\author{
Norbert Polčák*, Jakub Mészáros** \\ * Univerzita Komenského v Bratislave, Prírodovedecká fakulta, Katedra fyzickej geografie a geoekológie, \\ Ilkovičova 6,84215 Bratislava, norbert.polcak@uniba.sk \\ Slovenský hydrometeorologický ústav, Jeséniova 17,833 15 Bratislava, norbert.polcak@shmu.sk \\ ** Ústav hydrológie SAV, Dúbravská cesta 9, 84104 Bratislava, jakub.meszaros@stuba.sk \\ Slovenský hydrometeorologický ústav, Jeséniova 17, 83315 Bratislava, jakub.meszaros@shmu.sk
}

\begin{abstract}
The effect of relief on the distribution of atmospheric precipitation in Slovakia in the southern cyclonic situations

This article is focused on identifying windward and leeward places in the territory of Slovakia during southern cyclonic situations. These places arise due to relief that affects the distribution of precipitation by altitude and orientation to southern flow. Southern flows are an important source of moisture for southern Slovakia. Based on precipitation sums of all the rainfall gauges during the days with the southern cyclonic situations the precipitation fields were interpolated for the period 1991-2017. Using the created windward index, windward and leeward places on precipitation fields were mapped out. Based on the map outputs, the effect of the relief was analyzed on the wettest and driest places. It was found out that the most rainfall falls in the mountains in the southern part of central Slovakia. The results were compared with the predictions ALADIN and the ECMWF models and the precipitation field from the selected synoptic situation. The achieved results have been confirmed. Research results have practical uses in several areas, particularly in meteorology, hydrology and agriculture.
\end{abstract}

Key words: precipitation, relief, windward and leeward places, southern cyclonic situations, Slovakia

\section{ÚVOD}

Slovensko je rozlohou malá krajina, ale vd’aka členitému reliéfu a geografickej polohe je tam podnebie a počasie vel'mi rôznorodé. Vzhl'adom na polohu v strede Európy sa nad územím Slovenska striedajú kontinentálne aj oceánske vzduchové hmoty, prevláda západné až severozápadné prúdenie. So stúpajúcou nadmorskou výškou spravidla všeobecne pribúda množstvo zrážok, preto najvyššie úhrny padajú na severozápade územia a v najvyšších pohoriach, čo je väčšinou zapríčinené zonálnym prúdením a prísunom vlhkého vzduchu z Atlantického oceánu. Vyskytujú sa aj situácie, ked' vlhký vzduch do strednej Európy prúdi od Stredozemného mora v meridionálno-zonálnom a meridionálnom smere (SHMÚ 2009). O smere prúdenia rozhoduje aj rozloženie tlakových útvarov nad Atlantickým oceánom Severoatlantická oscilácia (NAO). Ked' je NAO v pozitívnej fáze, prúdenie je väčšinou zonálne. Ked’ je NAO v negatívnej fáze, prúdenie je často meridionálne (Labudová et al. 2013). Posledných 20 rokov sa častejšie vyskytuje pozitívna fáza (Lešková et al. 2012). Z toho vyplýva, že v roku klesá aj počet dní s južnými cyklonálnymi situáciami, čo môže spôsobovat' sucho v južných regiónoch Slovenska. 
Zrážky z južných cyklonálnych situácií zasahujú zväčša juh územia, ktorý je dôležitou pol'nohospodárskou oblast'ou. Počas dní s južnými cyklonálnymi situáciami dostáva táto čast' územia, najmä južné náveterné svahy pohorí, vysoké úhrny zrážok. Prejavuje sa tu efekt náveternosti a spôsobuje, že najviac zrážok spadne vo vyšších a kompaktných pohoriach, ktoré sú kolmo orientované na južné prúdenia. Voda z nich je odvedená väčšími riekami Hron, Nitra, Žitava, Ipel', Slaná a Rimava smerom na juh do úrodných nížin a kotlín. Významný výskyt južných cyklonálnych situácií je na jar a na jeseň. Zásoby vody v povodiach z južných cyklonálnych situácií sú dôležitým zdrojom vody pre krajinu počas roka. Na druhej strane, sú aj častou príčinou povodní na juhu Slovenska, ale aj v ostatných krajinách strednej Európy (Munzar et al. 2011).

Každodenná prax v Slovenskom hydrometeorologickom ústave nám potvrdzuje potrebu poznania priestorového rozloženia úhrnov atmosférických zrážok pri južných cyklonálnych situáciách $\mathrm{v}$ kontexte vydávania meteorologických a hydrologických výstrah pre konkrétne geografické regióny. $\mathrm{V}$ tomto článku je naším ciel'om identifikovat' na Slovensku geografické oblasti, ktoré sú najviac a najmenej ovplyvňované atmosférickými zrážkami pri južných cyklonálnych situáciách.

\section{PREHL'AD LITERATÚRY}

Atmosférickými zrážkami a vplyvom reliéfu na ich rozloženie sa zaoberalo viacero autorov. Orografickým zrážkam a ich rozdeleniu sa podrobnejšie venoval Houze (2012). Prechod vzduchovej hmoty cez prekážku vo forme pohoria je rozoberaný v diele Fyzika oblaků a srážek (Řezáčová et al. 2007). V tabul'kovej forme sú zrážkové úhrny zaznamenané v publikácii autorov Šamaj a Valovič (1981) Dlhodobé priemery úhrnu zrážok na Slovensku za obdobie rokov 1901 - 1970. Mapy s úhrnmi atmosférických zrážok za rôzne obdobia sú v mapovej časti diela Zrážkové pomery na Slovensku od autorov Šamaj a Valovič (1981). Maximálne denné úhrny zrážok na Slovensku v období rokov 1951 - 2000 spracovali v Národnom klimatickom programe SR autori Faško et al. (2000). Zrážkovým pomerom na Slovensku za obdobie rokov 1961 - 1990 sa venuje A tlas krajiny Slovenskej republiky (Miklós, ed. 2002) a za obdobie rokov 1961 - 2010 ich nájdeme v Klimatickom atlase Slovenskej republiky (Bochníček et al. 2015). Tieto publikácie charakterizujú rozloženie zrážok na Slovensku z dlhodobého hl'adiska. Na internetovej stránke Slovenského hydrometeorologického ústavu sú dostupné informácie o zrážkomernej sieti na Slovensku, zoznam staníc a metódy, ktoré sa používajú na monitorovanie zrážok.

Poveternostné situácie podrobne spracoval kolektív autorov Hydrometeorologického ústavu (1972) v Katalógu poveternostných situácií ČSSR. Charakter počasia počas vybraných poveternostných situácií na našom území sa nachádza v publikácii Počasie na územi Slovenska za typických poveternostných situácií (Ballon et al. 1964). Priamo na zrážky počas rôznych situácií je upriamená pozornost' v publikácii Srážky na území ČSSR při jednotlivých typech povětrnostní situace (Brádka 1972).

Závislost' medzi extrémnymi dennými úhrnmi zrážok a topografiou v Škótsku skúmali autori Prudhomme a Reed (1998), vplyvom nadmorskej výšky a vysokých úhrnov atmosférických zrážok vo francúzskych Alpách sa zaoberali napr. Kieffer et al. (2000). V pohoriach na rôznych miestach skúmali tento vzt'ah aj Basist et al. (1994). Všetky články potvrdzujú, že na množstvo zrážok má vplyv nadmorská 
výška a expozícia voči prúdeniu. Brázdil a Faško (1993) potvrdili túto zákonitost' aj pre naše územie v článku Orographic effects on precipitation distribution on the territory of the Slovak Republic, v ktorom na deviatich vybraných profiloch analyzujú náveterné a záveterné efekty rozloženia zrážok v lete a v zime vzhl'adom na charakter prúdenia v hladine $850 \mathrm{hPa}$. V Mad'arsku sa rovnakou témou zaoberal Ambrózy (1993). Na príklade pohoria Börzsöny zistil, že v lete spadne vo východnej časti pohoria menej zrážok ako $\mathrm{v}$ západnej a $\mathrm{v}$ zime je to približne vyrovnané, čo je spôsobené častejším severozápadným prúdením $\mathrm{v}$ lete a juhovýchodným $\mathrm{v}$ zime.

Konček et al. (1974) v publikácii Klíma Tatier zistili, že na severných svahoch Tatier sú zrážky výdatnejšie a častejšie ako na južných svahoch, z čoho vyplýva, že orientácia voči prevládajúcemu prúdeniu má väčší vplyv na množstvo zrážok ako nadmorská výška. Zaoberali sa aj množstvom zrážok počas rôznych poveternostných situácií a dokázali, že počas juhozápadnej cyklonálnej situácie dostávajú severné svahy Tatier menej zrážok ako je priemerné množstvo, čiže sa prejavuje zrážkový tieň.

Vzt’ah medzi zrážkovým pol'om a severnou až severozápadnou cyklonálnou situáciou na našom území je analyzovaný v článkoch The structure of the precipitation field at the north-western cyclonal situation in Slovakia a The structure of the precipitation field at the western cyclonal situation in Slovakia (Brázdil et al. 1991a a 1991b). V poslednom období sa však nikto nezaoberal danou problematikou, a preto je pre nás výzvou upriamit' pozornost' predovšetkým na južné cyklonálne situácie a ich prejavy na Slovensku.

\section{ÚDAJE A METÓDY}

Slovenský hydrometeorologický ústav (SHMÚ) nám v poskytol 24-hodinové úhrny zrážok s hodnotou $0,1 \mathrm{~mm}$ a viac zo všetkých zrážkomerných staníc na Slovensku (vyše 600), na ktorých sa uskutočňovalo meranie v rokoch 1991 až 2017. Neštandardné obdobie bolo zvolené z dôvodu, že od roku 1991 sa denne zaznamenáva typ poveternostnej situácie pre strednú Európu a je typizovaný v polročných intervaloch v spolupráci s Českým hydrometeorologickým ústavom, rok 2017 je zatial' rokom ukončenia výskumu. Zo spomenutého Katalógu poveternostných situácií ČSSR sme vychádzali pri rozdelení južných cyklonálnych situácií, ktoré sa líšia na základe rozloženia riadiacich tlakových útvarov, prechodom frontálnych zón a smerom prúdenia. Sú to: juhovýchodná cyklonálna situácia SEc, juhozápadná cyklonálna situácia $\mathrm{SWc1}$, juhozápadná cyklonálna situácia $\mathrm{SWc} 2$ a juhozápadná cyklonálna situácia SWc3. Schematicky sú znázornené na obr. 1.

Z dostupných metadát sme pre daný rok vylúčili stanice, na ktorých bolo ukončené alebo prerušené meranie, ked’že tieto stanice by sa ukazovali ako záveterné polohy (pri interpolácii by bol podl'a metodiky zarátaný úhrn $0 \mathrm{~mm}$ ). Následne sme z údajov vybrali úhrny počas dní, ked' sa podl'a kalendára poveternostných situácií vyskytol typ SEc, SWc1, SWc2 a SWc3. Údaje v prostredí Microsoft Excel sme otvorili v softvéri ArcCatalog. Úhrny, ktoré spadli počas jednotlivých situácií, sme v ArcCatalogu sčítali a získali sme výšku úhrnov za každú vybranú cyklonálnu situáciu v sledovanom období. Ďalej sme pracovali v softvéri ArcMap. Na základe geografických súradníc staníc sme funkciou Display XY Data zobrazili bodovú vrstvu a následným exportovaním bodov sme získali bodové úhrny pre každú situáciu. 


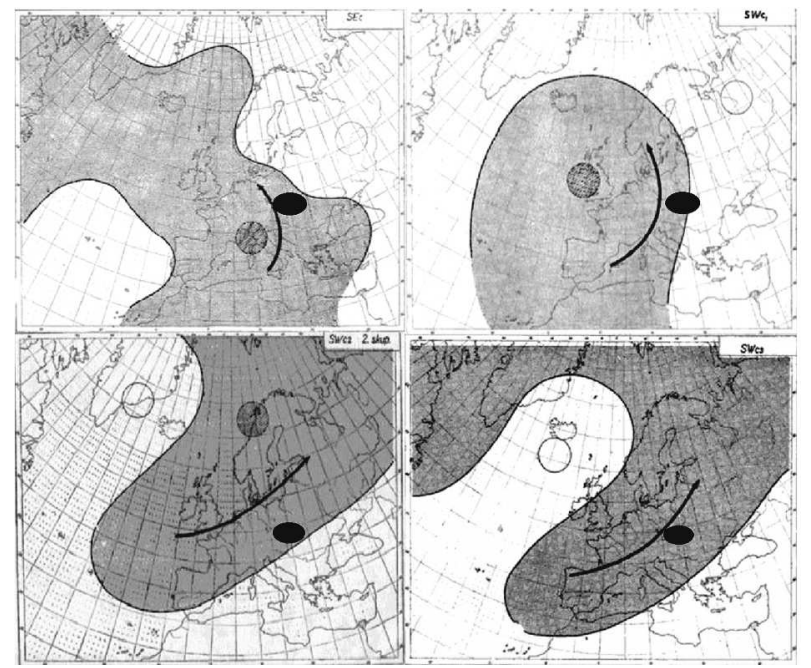

Obr. 1. Rozloženie riadiacich tlakových útvarov a smer prechodu frontálnych zón pri južných cyklonálnych situáciách nad strednou Európou

Zrážkové polia je možné vytvorit' pomocou rôznych metód z bodových meraní zrážkomermi alebo z merania meteorologického radaru. Odvodenie plošných zrážok nie je celkom presné, lebo je st’ažené priestorovou premenlivost'ou zrážok a regionálnymi klimatickými odlišnost’ami (Šercl 2008). My sme mali k dispozícii údaje z bodových meraní zo zrážkomerov. Podla Šercla (2008) sú najčastejšie metódy na interpoláciu bodových pozorovaní s ciel'om získania plošných zrážok nasledovné: metóda inverzne vážených vzdialeností, metóda ordinárneho krigingu s teoretickým sférickým modelom semivariogramu, metóda Topo to Raster, metóda tzv. orografickej interpolácie a metóda korekcie radarového pol’a zrážok. Pre nás bola vhodná metóda Topo to Raster, ked’že je $\mathrm{v}$ diele tohto autora uvedená ako metóda primárne určená na generovanie hydrologicky korektného modelu reliéfu z výškových bodov a vrstevníc, ale rovnako vhodné môže byt' aj na interpolovanie bodovo meraných zrážok. Táto metóda umožňuje výpočet odhadu interpolovanej hodnoty zo štyroch susedných bodov, pričom využiva iteračnú metódu konečných diferencií a izolínie vytvorené touto metódou sa najviac podobajú izolíniám, ktoré by odborník nakreslil ručne do papierovej mapy. Vel'kou výhodou tohto interpolačného nástroja je, že ponúka možnost' nastavit' potrebné a vhodné parametre. Uvedenou interpoláciou sme vytvorili 348 zrážkových polí Slovenska pri poveternostných situáciách SEc, SWc1, SWc2 a SWc3, ktoré sa vyskytli v období rokov 1991 až 2017. Nástrojom Raster Calculator sme zrážkové polia sčítali. Sčítaním sme dostali zrážkové pole s celkovým úhrnom pri všetkých juhozápadných, juhovýchodných a všetkých južných cyklonálnych situáciách.

Aby sme na zrážkových poliach mohli objektívne identifikovat' náveterné a záveterné polohy, museli sme navrhnút' index náveternosti. Rozhodli sme sa pre rozdelenie zrážkového pol’a na sedem intervalov: silne záveterné, záveterné, mierne záveterné, neutrálne, mierne náveterné, náveterné a silne náveterné polohy. Pomocou softvéru ArcMap 10 sme pre zrážkové pole vypočítali priemernú hodnotu bunky rastra, ktorú sme určili ako strednú hodnotu. Rozdiel strednej hodnoty a mini- 
málnej hodnoty bunky rastra sme rozdelili v pomere 10:30:30:30. Prvých $10 \%$ tohto rozdielu boli neutrálne polohy, 10 - 40\% mierne záveterné polohy, 40 $70 \%$ záveterné polohy a 70 - $100 \%$ silne záveterné polohy. Aj rozdiel maximálnej hodnoty bunky a priemernej hodnoty bunky rastra sme rozdelili $\mathrm{v}$ rovnakom pomere a $10 \%$ tohto rozdielu boli neutrálne polohy, $10-40 \%$ mierne náveterné polohy, $40-70 \%$ náveterné polohy a $70-100 \%$ silne náveterné polohy. Na mapovom výstupe sú najsuchšie miesta znázornené bielou farbou, ktorá pri neutrálnych polohách prechádza do šedej, a najvlhšie miesta sú čierne.

Pomocou mapových výstupov sme charakterizovali náveterné a záveterné polohy, analyzovali sme vplyv nadmorskej výšky a orientácie reliéfu voči južnej expozícii. Výsledky sme overili porovnaním s reálnou situáciou so zrážkovými pol’ami, ktoré pre situáciu trvajúcu od 14. 10. 2015 do 17. 10. 2015 vypočítali predpovedné modely Aladin a ECMWF a so zrážkovým pol'om vytvoreným interpoláciou úhrnov zo zrážkomerných staníc počas tohto štvordňového obdobia. Výstupy z modelov, rovnako ako úhrny zrážok, nám opät' poskytol SHMÚ. Pre lepšiu orientáciu sme vytvorili mapu geomorfologických celkov Slovenska so siet'ou zrážkomerných staníc (obr. 2). Geomorfologické celky v tomto článku sú rozčlenené podl'a publikácie Nižiny, kotliny a pohoria Slovenska (Lukniš a Plesník 1961).

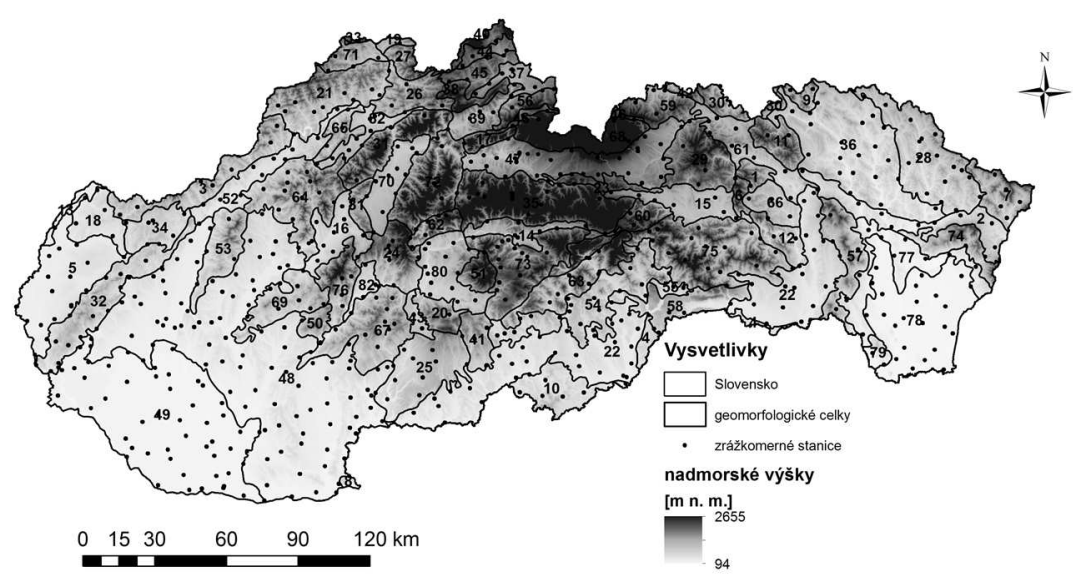

Obr. 2. Nadmorské výšky, geomorfologické celky Slovenska a zrážkomerná siet' SHMÚ

\section{VÝSLEDKY A DISKUSIA}

\section{Zrážkové polia \\ Juhozápadná cyklonálna situácia $S W c 1$}

Pri juhozápadných cyklonálnych situáciách SWc1 (obr. 3) sa silne náveterné polohy nachádzajú v Tatrách (na obr. 2 celok číslo 68), v d'umbierskej časti Nízkych Tatier (35), v Starohorských vrchoch (62), v Kremnických vrchoch (24) a v Revúckej vrchovine v Slovenskom rudohorí (54). Tatry sú svojou výškou najväčšou prekážkou v okolí. Dumbierske Tatry spolu so Starohorskými a Kremnickými vrchmi vytvárajú pre vzduchové hmoty prúdiace od juhozápadu ponad Zvolenskú kotlinu (80) kompaktnú bariéru, preto sa tu úhrny výrazne zvyšujú. Náveterné sú aj Štiavnické vrchy (67), ktoré nie sú až tak vysoké, ale od juhozápadu sa dvíhajú 
z Podunajskej nížiny (48 a 49) a zachytávajú zrážky prichádzajúce z tohto smeru. Vtáčnik (76) síce leží za pohorím Tribeč (69), ale je podstatne vyšším a masívnejším pohorím, preto je tu efekt náveternosti silnejší ako v Tríbeči. Podobne je to aj V prípade nižšieho Považského Inovca (53) a náveterných Strážovských vrchov (64). Rozsiahle a súvislé náveterné polohy sú v Slovenskom rudohorí $(54,63,73$ a 75).

Silne záveterné polohy sú v okolí Oravskej kotliny (37), ktorá je chránená od juhozápadu Oravskou Magurou (38), v Pieninách (42) a v Lubovnianskej vrchovine (30) v tieni Vysokých Tatier (68) a Levočských vrchov (29). Zrážkový tieň sa prejavuje aj na Ondavskej vrchovine (36), ktorá je od juhozápadu chránená Čergovom (11), Sarišskou vrchovinou (66) a Slanskými vrchmi (57). Menšie množstvo zrážok spadne predovšetkým na nížinách. Záveterné polohy sa nachádzajú prevažne v kotlinách tienených od juhozápadu susednými pohoriami: Podtatranská (47), Košická a Rimavská kotlina, ktorá sú podcelkami Juhoslovenskej kotliny (22) a Spišsko-šarišské medzihorie (61).

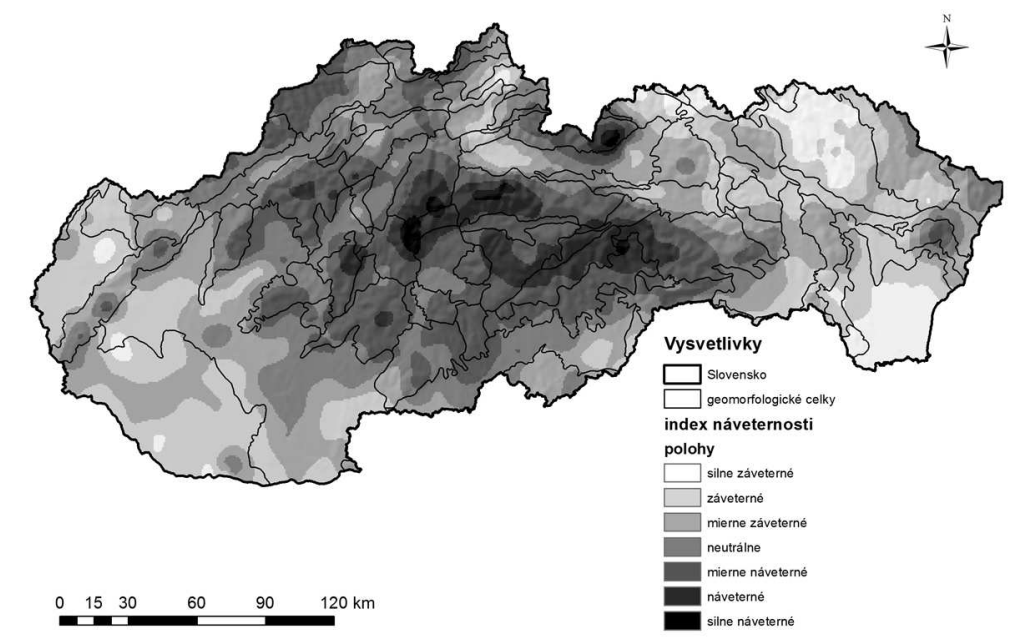

Obr. 3. Zrážkové pole počas juhozápadných cyklonálnych situácií SWc1

\section{Juhozápadná cyklonálna situácia $S W c 2$}

Počas cyklonálnych situácií SWc2 (obr. 4) spadne najväčšie množstvo zrážok v Tatrách (68) a v d’umbierskej časti Nízkych Tatier (35). Sú to naše najvyššie pohoria a výraznú úlohu tu zohráva pribúdanie zrážok so stúpajúcou nadmorskou výškou. Pri tejto situácii dostáva pomerne vel'a zrážok severozápad Slovenska, konkrétne pohoria Javorníky (21), Kysucká vrchovina (27), Kysucké Beskydy (26), Oravská Magura (38), Malá Fatra (31), Vel'ká Fatra (72) a aj západná čast' Tatier (68). Je to $\mathrm{z}$ toho dôvodu, že počas situácie SWc2 má prúdenie viac zonálny smer zo západu ako meridionálny z juhu. Náveterné sú Kremnické (24) a Starohorské vrchy (62). Vysoké úhrny sa vyskytujú aj v našich najvýchodnejších pohoriach vo Vihorlate a Bukovských vrchoch. Pri situácii SWc1 a SEc spadne vo východnej tretine územia menej zrážok ako v centrálnej a západnej. Náveterný efekt sa ukazuje vo Vihorlate (74) a v Poloninách (2). Aj pri týchto situáciách sa prejavuje záko- 
nitost', že kotliny sú v tieni pohorí, hoci nie až tak výrazne ako pri predchádzajúcich situáciách. Najmenej zrážok spadne na nížinách, hlavne na Podunajskej nížine (48 a 49). Všeobecne menej zrážok spadne na juhu Slovenska, čo je spôsobené spomínaným smerom postupu vzduchových hmôt počas tejto situácie.

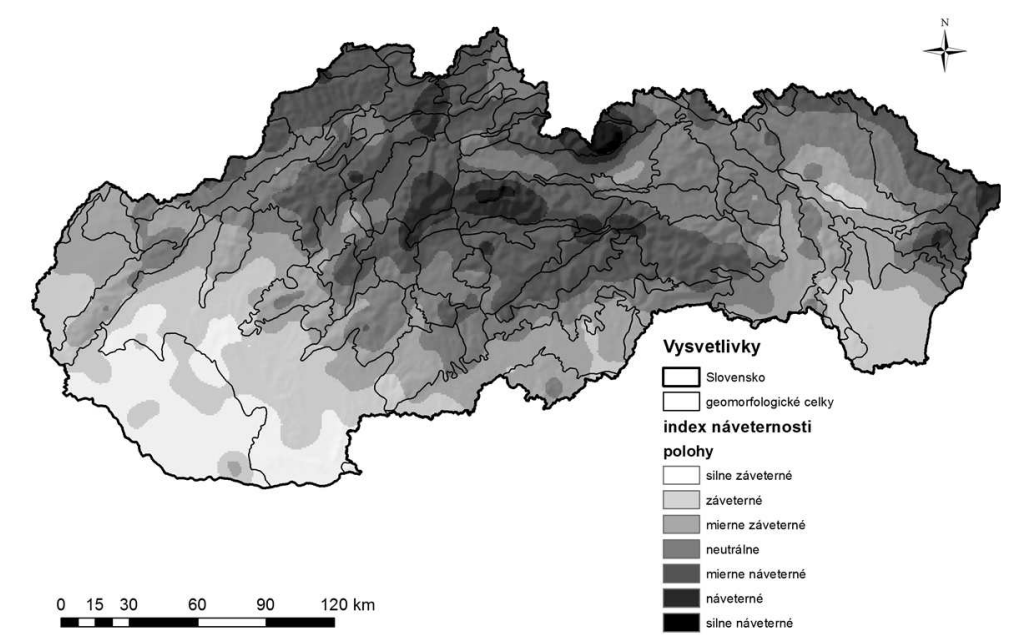

Obr. 4. Zrážkové pole počas juhozápadných cyklonálnych situácií SWc2

\section{Juhozápadná cyklonálna situácia SWc3}

Poveternostná situácia SWc3 (obr. 5) sa od situácie SWc2 líši iba rozložením tlakových útvarov. Preto sú na zrážkových poliach náveterné a záveterné polohy podobné.

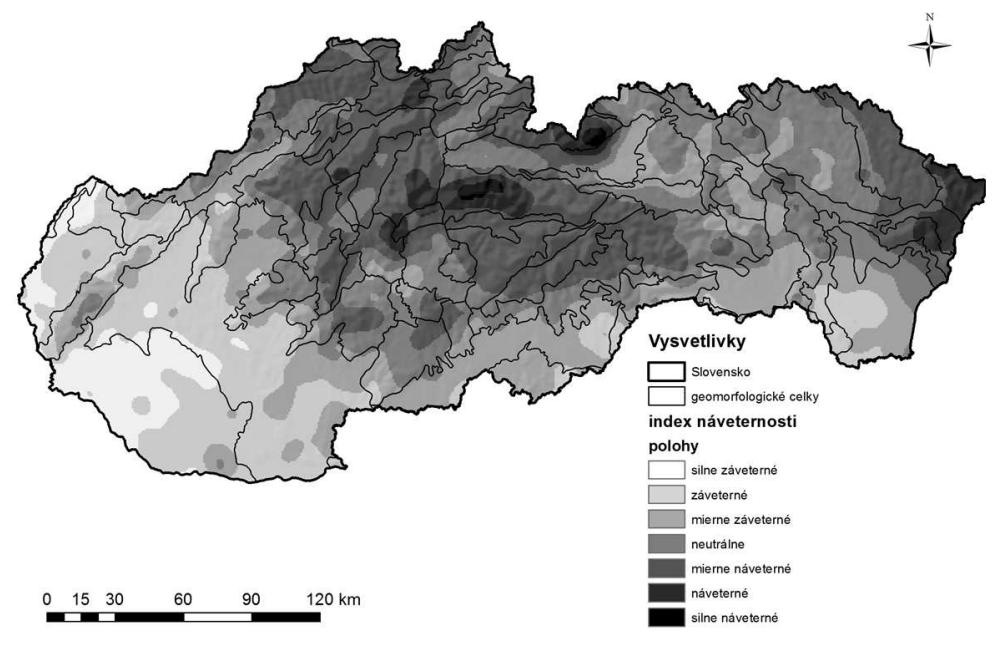

Obr. 5 Zrážkové pole počas juhozápadných cyklonálnych situácií SWc3 


\section{Juhovýchodná cyklonálna situácia SEc}

Pri juhovýchodných situáciách SEc (obr. 6) sú silne náveterné polohy v Malých Karpatoch (32) a vo východnej časti Kremnických vrchov (24). Malé Karpaty majú smer juhozápad - severovýchod, sú exponované voči juhovýchodnému prúdeniu a aj napriek pomerne malej výške sú prvou výraznou prekážkou pre vzduchové hmoty prichádzajúce z juhovýchodného smeru ponad Podunajskú nížinu (48 a 49). Východné svahy Kremnických vrchov zachytávajú zrážky, ktoré prešli ponad zníženinu medzi Ostrôžkami (48), Javorím (20) a Pol'anou (51), Veporskými vrchmi (73) a ponad Zvolenskú kotlinu (80). Nízka Krupinská planina (25) nie je prekážkou pre vzduchové hmoty prichádzajúce od juhovýchodu, tie zastavia až vyššie Štiavnické vrchy (67) a ešte vyšší Vtáčnik (76), takže tieto dve pohoria sú podla indexu tiež náveterné. Súvislú prekážku v smere juhozápad - severovýchod tvoria pohoria Slovenského rudohoria: Veporské vrchy (73), Stolické vrchy (53), Revúcka vrchovina (54), Spišsko-gemerský kras (60), Volovské vrchy (75). Aj ked’ Tatry (68) ležia na severe Slovenska a z juhovýchodu sú chránené viacerými pohoriami, sú najvyšším pohorím a prejavuje sa tu nárast množstva zrážok so stúpajúcou nadmorskou výškou.

Pri týchto situáciách spadne najmenej zrážok v kotlinách na severozápade Slovenska, ktoré sú chránené od juhovýchodu vysokými pohoriami. Podobne je to aj v prípade oblastí na Liptove a Orave. Silne záveterné oblasti sú aj na severovýchode Slovenska. Môže to byt' spôsobené tým, že situácie SEc zasahujú viac západ a stred Slovenska ako východ, ked’že aj Podunajská nížina (48 a 49) dostáva výrazne viac zrážok ako Východoslovenská nížina (78 a 79). Východ Slovenska je od juhovýchodu v tieni Karpatského oblúka tiahnuceho sa cez Ukrajinu a Rumunsko. Záveterné sú kotliny Považského podolia (52), chránené od juhovýchodu Strážovskými vrchmi (64), Turčianska kotlina (70) v tieni Vel'kej Fatry (72) a Kremnických vrchov (24), Hornádska kotlina (15) v tieni Slovenského rudohoria a oblasti na severovýchode Slovenska.

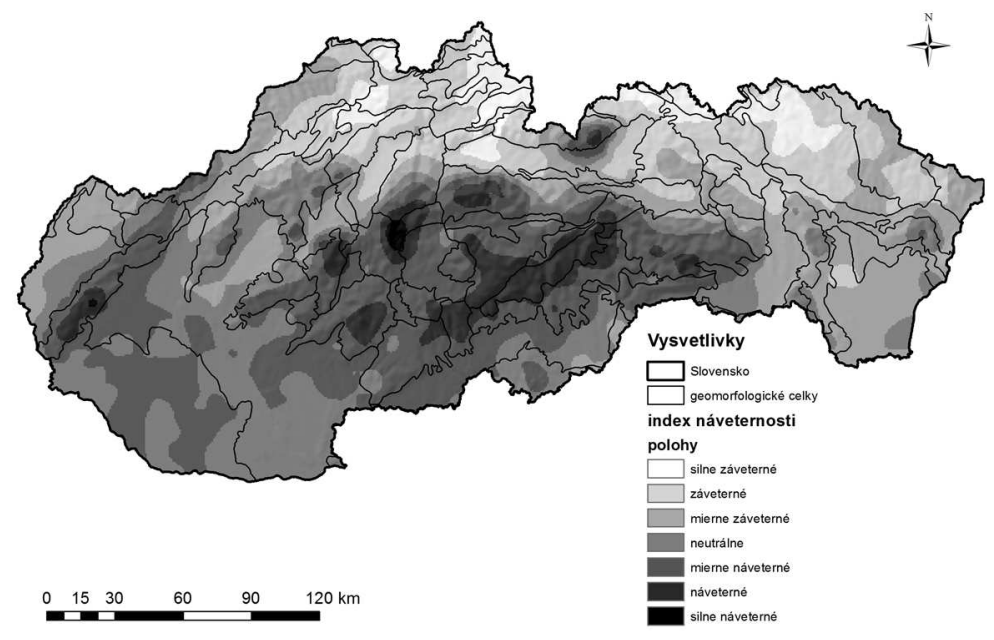

Obr. 6 Zrážkové pole počas juhovýchodných cyklonálnych situácií SEc 
Na obr. 7 je výsledná mapa vytvorená sčítaním 348 zrážkových polí počas všetkých južných cyklonálnych situácí́ za obdobie rokov 1991 - 2017. Mapa zobrazuje náveterné a záveterné polohy získané indexom náveternosti.

Najviac náchylné miesta na zrážky počas týchto situácií sa nachádzajú v Tatrách (68), v Dumbierskych Tatrách (35) a v Kremnických vrchoch (24). Tatry sú najvyšším pohorím na Slovensku, prejavuje sa tu pribúdanie zrážok s rastúcou nadmorskou výškou. Zrážkomerné stanice Skalnaté pleso a Lomnický štít sú od juhu dobre dostupné pre vzduchové hmoty. Rozdiel medzi západnou a východnou čast’ou Tatier je pravdepodobne spôsobený absenciou zrážkomerných staníc v západnej časti Tatier s podobnou polohou ako Lomnický štít a Skalnaté pleso, ked’že stanice Zuberec-Zverovka a Vitanová-Oravice sú od juhu v zrážkovom tieni.

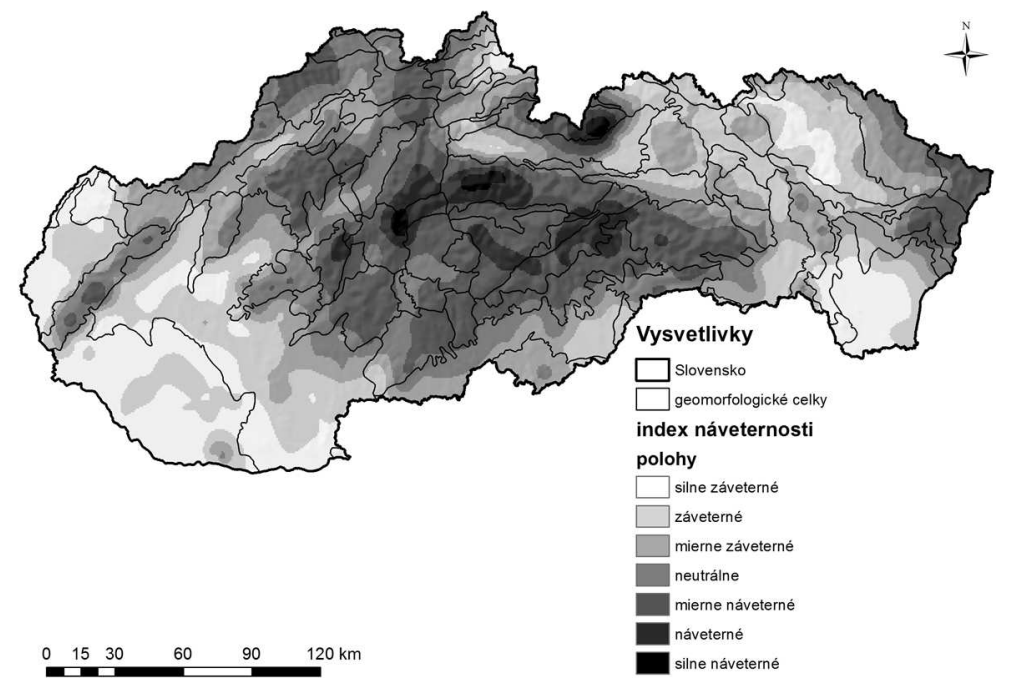

Obr. 7. Zrážkové pole počas všetkých južných cyklonálnych situácií

Rozdiel môže byt' spôsobený aj tým, že západná čast' Tatier je nižšia ako východná a nachádza sa za vyššími d’umbierskymi Nízkymi Tatrami, vyššia východná čast' Tatier je za nižšími Král'ovohol'skými Tatrami (podcelok Nízkych Tatier). Podobne je to aj v prípade Nízkych Tatier. Vyššia d'umbierska čast' leží za nižšími vrchmi Slovenského rudohoria a nižšia král'ovohol'ská čast' je za vyššími vrchmi Slovenského rudohoria (54, 60, 63, 73 a 75). Východné svahy Kremnických vrchov vytvárajú kompaktnú bariéru pre zrážky, ktoré prešli ponad nižšie pohoria od juhu a Zvolenskú kotlinu (80). Náveterné je pohorie Vtáčnik (76), ktoré je vyššie ako okolité južnejšie pohoria, a preto dostáva viacej zrážok. Vel'a zrážok spadne na južných a svahoch Starohorských vrchov (62) a Vel'kej Fatry (72). Svojím západovýchodným smerom vytvárajú vysokú a súvislú prekážku pohoria Slovenského rudohoria. Vel'ké úhrny sú v jeho najvyšších pohoriach: Veporských vrchoch (73), Stolických vrchoch (63), Revúckej vrchovine (54), Volovských vrchoch (75), v ich dolinách s južnou expozíciou (stanice Klenovec, Muráň, Ratkovské Bystré a Slavošovce) a na južnom úpätí Spišsko-gemerského krasu (60); (Dedinky, Dobšinská l'adová jaskyňa a Mlynky). Potvrdzuje sa, že aj nižšie pohoria v južnej časti Slovenska - napr. Malé Karpaty (32), Štiavnické vrchy (67), Krupinská planina (25), 
Javorie (20), Ostrôžky (41), Pol'ana (51), Slovenský kras (58) a Vihorlat (74) dostávajú viac zrážok ako ovel'a vyššie pohoria v severnej časti Slovenska. Najmenej zrážok spadne na nížinách. Pri situáciách SEc dostáva Podunajská nížina (48 a 49) pomerne vel'a zrážok, ale pri situáciách SWc je v zrážkovom tieni Álp, rovnako ako aj Záhorská nížina (5 a 18). Východoslovenká nížina (78 a 79) je vo východnej časti Slovenska, ktorá nebýva pri situáciách SEc zasiahnutá vysokými úhrnmi a pri SWc situáciách je v tieni mad'arského pohoria Zemplínske vrchy. Chudobná na zrážky je Ondavská vrchovina (36). Ako bolo spomenuté, východ nezasahujú vysoké úhrny počas situácií SEc a z juhozápadu je Ondavská vrchovina v závetrí viacerých pohorí. Ešte menej zrážok ako na nížinách spadne na severe Slovenska v Oravskej kotline (37), ktorá je silne záveterná. V závetrí okolitých pohorí sú aj d'alšie kotliny: Trenčianska a Ilavská na Považskom podolí (52), Podtatranská (47), Hornádska (15) a Spišsko-šarišské medzihorie (61). Záveterné sú aj pohoria na severovýchode: Pieniny (42), Spišská Magura (59), Lubovnianska vrchovina (30). V závetrí mad’arských pohorí sú podcelky Juhoslovenskej kotliny (22) - Košická a Rimavská. Zrážkový tieň vzniká aj severne od Vihorlatu (74).

\section{Porovnanie s reálnou situáciou}

Od 14. októbra 2015 do 18 . októbra 2015 sa v prízemnom tlakovom poli nad južnými Alpami nachádzala plytká tlaková níž (obr. 8). Vo výškovej hladine 700 a $500 \mathrm{hPa}$ bola hlboká tlaková níž. S ňou spojené frontálne rozhranie, oddel'ujúce teplejší vzduch nad juhovýchodnou Európou od chladnejšieho vzduchu nad západnou Európou, ovplyvňovalo počasie na Slovensku.

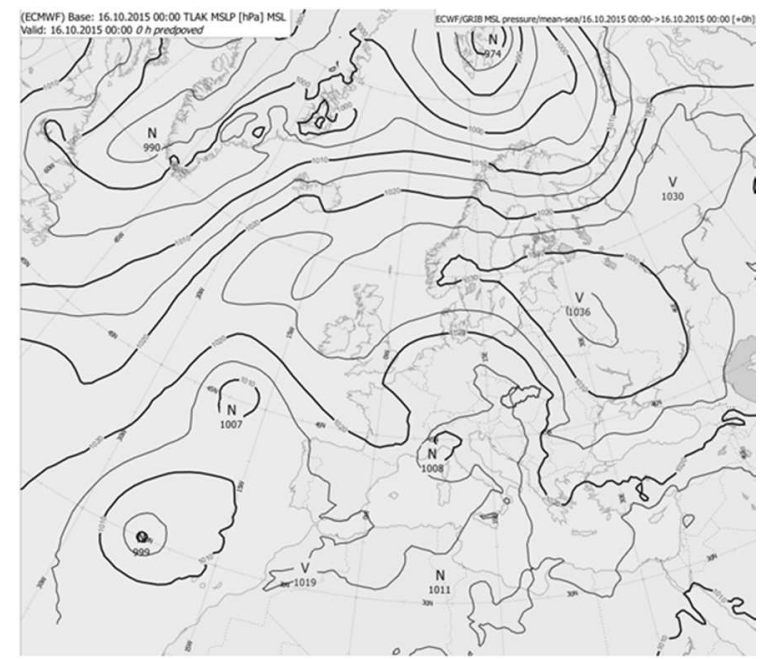

Obr. 8. Prízemné tlakové pole nad Európou 16. 10. 2015

\section{Model ALADIN}

Na obr. 9 je grafický výstup z predpovedného modelu ALADIN z 15. 10. 2015 o 00:00 UTC. Model predpovedal, že za najbližších 72 hodín spadne na najexponovanejších miestach Slovenska počas juhovýchodnej cyklonálnej situácie SEc tak- 
mer 100 mm zrážok. Najviac atmosférických zrážok predpovedal pre Kremnické vrchy, Starohorské vrchy, pohoria v Slovenskom rudohorí, Stiavnické vrchy a Strážovské vrchy. Najmenej zrážok model predpovedal na severe Slovenska, v nížinách a kotlinách v zrážkovom tieni okolitých pohorí.

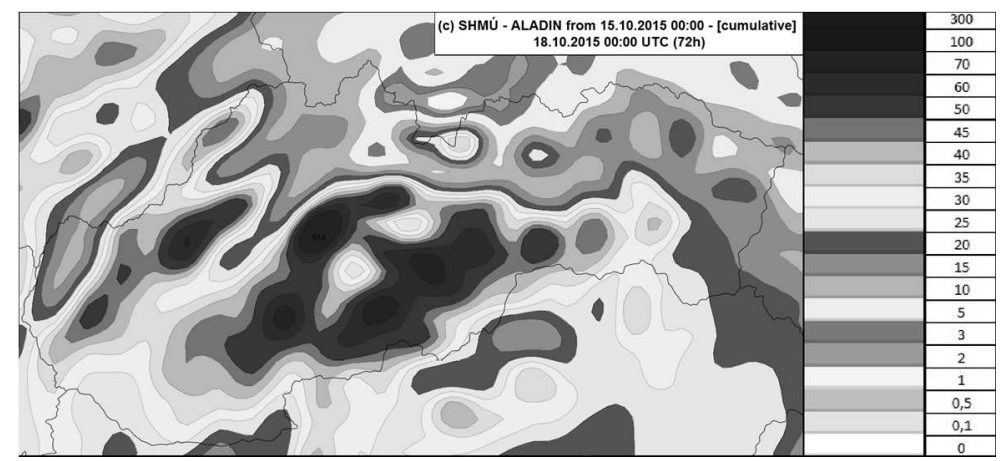

Obr. 9. Predpoved' kumulatívnych úhrnov atmosférických zrážok od 15. 10. do 18. 10. 2015 predpovedným modelom ALADIN

\section{Model ECMWF}

Model ECMWF má menšie rozlíšenie a nerozlišuje reliéf tak dobre ako model ALADIN. Z 15.10.2015 o 00:00 UTC predpovedal na najbližších 72 hodín taktiež najviac zrážok pre pohoria v centrálnej časti a na juhu stredného Slovenska. Najmenej zrážok odhadoval na severe, severovýchode a východe Slovenska (obr. 10).

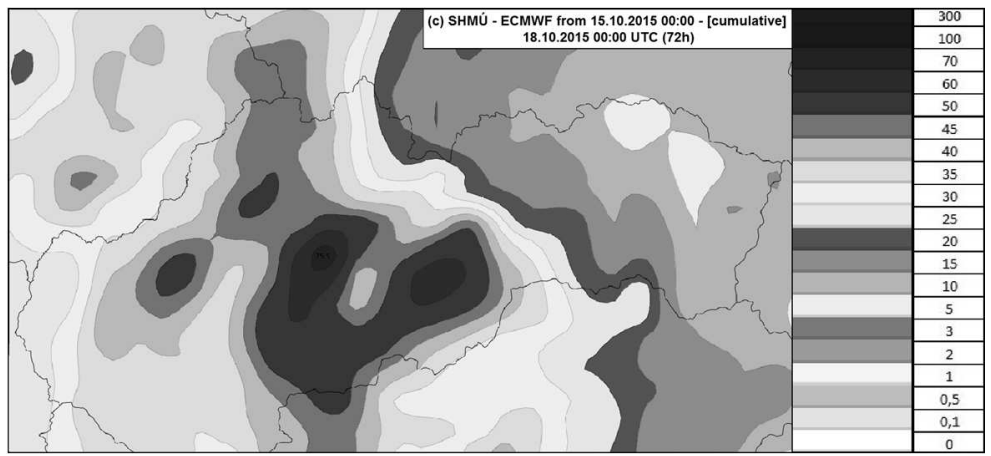

Obr. 10 Predpoved' kumulatívnych úhrnov atmosférických zrážok od 15. 10. do 18. 10. 2015 predpovedným modelom ECMWF

\section{Reálne úhrny}

Na obr. 11 je zrážkové pole vytvorené interpoláciou reálne nameraných úhrnov z aktuálnych zrážkomerných staníc počas juhovýchodnej situácie SEc trvajúcej od 15. októbra 2015 do 18. októbra 2015. Najvyššie úhrny (vyše $100 \mathrm{~mm}$ za 72 hodín) boli v Nízkych Tatrách (na obr. 1 celok číslo 35), Kremnických (24) a Starohorských vrchoch (62). Vysoké úhrny spadli aj v pohoriach Malé Karpaty (32), Vtáč- 
nik (76), Štiavnické vrchy (67), Krupinská planina (25), Javorie (20), Ostrôžky (41), v pohoriach Slovenského rudohoria: Revúckej vrchovine (54), Veporských (73), Stolických (63), Volovských vrchoch (75), Spišsko-gemerskom krase (60) a v Slovenskom krase (58). Najmenej zrážok spadlo na severe a severovýchode Slovenska.

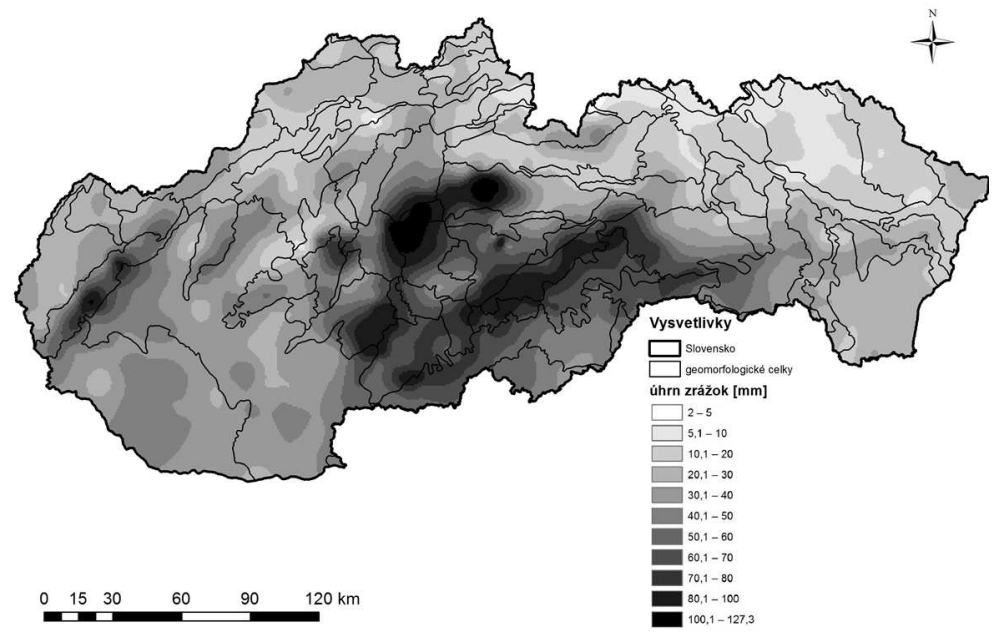

Obr. 11. Zrážkové pole vytvorené z nameraných úhrnov od 15. 10. do 18. 10. 2015

Na základe porovnania obr. 9 a 10 možno konštatovat', že predpovedný model Aladin dokáže pomerne presne identifikovat' náveterné a záveterné polohy, vzhl'adom na svoje lepšie rozlíšenie reliéfu. Polohy sa, samozrejme, úplne nezhodujú, ked’že je to len matematický model a v realite sa počasie môže správat' inak. Napriek tomu je tento model výbornou pomôckou pre meteorológov, ktorí spolu so svojimi skúsenost'ami a vedomost'ami dokážu vytvorit' presnú predpoved' počasia. Rozloženie zrážok správne predpovedal aj predpovedný model ECMWF, hoci má menšie rozlíšenie ako model Aladin. Z porovnania zrážkových polí na obr. 6 a 11 je možné vidiet', že najdaždivejšie a najsuchšie oblasti sa zhodujú, teda aj pri reálnej poveternostnej situácii sa potvrdili náveterné a záveterné polohy vytvorené indexom náveternosti.

\section{ZÁVER}

Naším ciel'om bolo identifikovat' náveterné a záveterné polohy na Slovensku pri juhozápadnej cyklonálnej situácii SWc1, juhozápadnej cyklonálnej situácii SWc2, juhozápadnej cyklonálnej situácii SWc3 a juhovýchodnej cyklonálnej situácii SEc. $\mathrm{Na}$ splnenie ciel'a sme si stanovili vlastnú metodiku. Výsledky sme porovnali $\mathrm{s}$ predpovednými modelmi a s reálne nameranými údajmi.

Výsledky majú využitie v praxi pre meteorológov, hydrológov alebo pol'nohospodárov. Pomocou mapy môžu meteorológovia presnejšie určit' miesta, pre ktoré bude platit' výstraha pred vysokými úhrnmi zrážok pri očakávanej južnej cyklonálnej situácii. Hydrológovia môžu podrobnejšie lokalizovat' povodia tokov, na ktorých hrozí vzostup vodných hladín alebo povodeň a kde možno v zimnej sezóne 
očakávat' zvýšenie zásob vody v snehovej pokrývke. Juh našej krajiny je dôležitou pol'nohospodárskou oblast'ou a vlaha $\mathrm{v}$ tejto časti Slovenska je závislá od zrážok spadnutých počas južných cyklonálnych situácií. Preto je potrebné venovat' sa danej problematike aj nad'alej.

\section{Za poskytnuté údaje d’akujeme Slovenskému hydrometeorologickému ústavu.}

\section{LITERATÚRA}

AMBRÓZY, P. (1993). The effect of mountains on the distribution of precipatation in Hungary. Sixteenth International Conference on Carpathian Meteorology, 1, 81-85.

BALLON, L., FORGÁČ, P., MOLNÁR, F. (1964). Počasie na územi Slovenska za typických poveternostných situácií. Praha (Hydrometeorologický ústav).

BASIST, A., BELL, G., MEENTMEYER, V. (1994). Statistical relationships between topography and precipitation patterns. Journal of Climate, 7, 1305-1315.

BOCHNIČEK, O., BORSÁNYI, P., ČEPČEKOVÁ, E., FAŠKO, P., CHMELÍK, M., JANČOVIČOVÁ, L., KAJABA, P., KAPOLKOVA, H., LABUDOVÁ, L., MIŠAGA, O., NEJEDLÍK, P., PRIBULLOVA, A., SNOPKOVÁ, Z., ŠŤASTNÝ, P., ŠVEC, M., TURÑA, M. (2015). Klimatický atlas Slovenska. Bratislava (Slovenský hydrometeorologický ústav).

BRÁDKA, J. (1972). Srážky na území ČSSR při jednotlivých typech povětrnostní situace. Sborník praci Hydrometeorologického ústavu, 18, 8-62.

BRÁZDIL, R., FAŠKO, P. (1993). Orographic effects on precipitation distribution on the territory of the Slovak Republic. In Sixteenth International Conference on Carpathian Meteorology, 1, pp. 86-91.

BRÁZDIL, R., FASKO, P., KOŠŤÁLOVÁ, J. (1991a). The structure of the precipitation field at the north-western cyclonal situation in Slovakia. Montainous Meteorolgy, Climatology and Aerology of the Lower Layers of Troposphere, pp. 75-82.

BRÁZDIL, R., FAŠKO, P., KOŠT́ÁLOVÄ, J. (1991b). The structure of the precipitation field at the western cyclonal situation in Slovakia. In $X V$ International Conference on Carpathian Meteorology, pp. 19-24.

FAŠKO, P., LAPIN, M., STASTNÝ, P. (2000). Maximálne denné úhrny zrážok na Slovensku v období 1951 - 2000. Národný Klimatický program SR. Bratislava (Ministerstvo životného prostredia Slovenskej republiky, Slovenský hydrometeorologický ústav).

HOUZE, R. A., Jr. (2012). Orographic effects on precipitating clouds. Reviews of Geophysics, 50, 47.

HYDROMETEOROLOGICKÝ ÚSTAV (1972). Katalog povětrnostnich situací pro území ČSSR. Praha (Hydrometeorologický ústav).

KIEFFER WEISSE, A., BOIS, P. (2001). Topographic effects on statistical charakteristics of heavy rainfall and mapping in the French Alps. Journal of Applied Meteorology, 40, 720-740.

KONČEK, M. et al. (1974). Klima Tatier. Bratislava. (Veda).

LABUDOVÁ, L., Ś̉TASTNÝ, P., TRIZNA, M. (2013). The North Atlantic oscillation and winter precipitation totals in Slovakia. Moravian Geographical Reports, 21(4), 38-49.

LEŠKOVA, L., ŠŤASTNÝ, P., TRIZNA, M. (2012). Analýza vplyvu severoatlantickej oscilácie na sezónne úhrny zrážok v zrážkových oblastiach Slovenska. Meteorologický časopis, 15, 75-80.

LUKNIS, M., PLESNÍK, P. (1961). Nižiny, kotliny a pohoria Slovenska. Martin (Osveta).

MIKLÓS, L., ed. (2002). Atlas krajiny Slovenskej republiky. Bratislava, Banská Bystrica (Ministerstvo životného prostredia SR a Slovenská agentúra životného prostredia).

MUNZAR, J., ONDRÁČEK, S., AUER, I. (2011). Central European one-day precipitation records. Moravian Geographical Reports, 19, 32-40. 
PRUDHOMME, C., REED, D. (1998). Relationships between extreme daily precipitation and topography in a mountainous region: a case study in Scotland. International Journal of Climatology, 18, 1439-1453.

ŘEZÁČOVÁ, D., NOVÁK, P., KAŠPAR, M., SETVÁK, M. (2007). Fyzika oblaků a srážek. Praha (Academia).

SHMÚ (2009). Klimatické pomery Slovenskej republiky, [Online]. Dostupné na: http:// www.shmu.sk/sk/?page=1064 [cit: 22-12-2017].

SHMÚ. Siet' zrážkomerných staníc, [Online]. Dostupné na: http://www.shmu.sk/sk/? page $=309$ [cit: 11-12-2017].

ŠAMAJ, F., VALOVIČ, Š. (1978). Dlhodobé priemery úhrnu zrážok na Slovensku za obdobie 1901 - 1970. Bratislava (Alfa).

ŠAMAJ, F., VALOVIČ, Š. (1981). Zrážkové pomery na Slovensku. Mapová čast'. Bratislava (Alfa).

ŠERCL, P. (2008). Hodnocení metod odhadu plošných srážek. Meteorologické zprávy, 61, 33-43.

Norbert Polčák, Jakub Més záros

\section{THE EFFECT OF RELIEF ON THE DISTRIBUTION OF ATMOSPHERIC PRECIPITATION IN SLOVAKIA IN THE SOUTHERN CYCLONIC SITUATIONS}

The main goal was to identify the windward and leeward places in Slovakia at the southwest cyclonic situation SWc1, the southwest cyclonic situation SWc2, the southwest cyclonic situation SWc3 and the southeast cyclonic situation SEc. To achieve the goal, the authors set their own methodology. The effect of relief on the distribution of atmospheric precipitation was analyzed for each of the four southern cyclonic situations and together for all cyclonic situations. It has been found that, in general, during southern cyclonic situations there are strongly windward places such as in the Tatry mountains, Nízke Tatry mountains and Kremnické vrchy mountains. Strongly leeward places are in all Slovakian lowlands, the northwestern part of Slovakia, the Oravská kotlina basin and the Podtatranská kotlina basin in northern Slovakia. The results were compared with prediction models and real measured data. Comparing the results achieved by our methodology with the results of the predictive models ALADIN, ECMWF and the rainfall totals that fell during the southeastern cyclonic situation SEc from October 15 to October 19, 2015 it was confirmed that windward and leeward places are similar. The results could be used in practice for meteorologists, hydrologists or farmers. By using the map, meteorologists can more accurately determine locations for which a warning will be issued before high rainfall in the expected south cyclone situation. Hydrologists can more accurately locate river basins that are at risk of rising water levels or floods, and expect an increase in snow cover in the winter season. The south of our country is an important agricultural area, and the water in this part of Slovakia is dependent on the precipitation that fell during the southern cyclonic situations. That is why it is necessary to pay attention to this topic also in the future. 